\title{
RETHINKING THE THEORY OF STATE OF EXCEPTION AFTER THE CORONAVIRUS PANDEMIC? - THE CASE OF HUNGARY
}

This article focuses on today's most important debate on emergency theory in the context of coronavirus pandemic. The theory of the state of exception in constitutional law is a matured one in a global point of view. Nevertheless, after the measures taken by the Hungarian Government, there are real concerns on the applicability of the classical theories. The paper reflects on the mentioned issue by presenting the so-called classic theories of this phenomenon and also the most relevant measures taken by the Hungarian government in 2020. The question remains: is it possible to preserve constitutionalism in an age of state of emergencies?

Keywords: state of exception, emergency models, the rule of law, Hungary, coronavirus

\section{INTRODUCTORY REMARKS}

Emergencies are mostly sudden, and states in most cases are using extraordinary measures to deal with them. For this reason, constitutional democracies have standing constitutional or exceptional legal powers to derogate constitutional values for the sake of order. Those democracies that do not have such powers use impromptu ones. The main subject of this paper is exceptional situations, the emergencies and the possible responses of states to these with particular attention to the coronavirus pandemic. The topic is always actual because there are countless emergencies in the world (such as civil wars, terrorist attacks, economic emergencies, natural disasters, industrial accidents, not to mention the climate change and its effects on modern states and societies) and it seems that this is an ever-increasing problem in constitutional democracies.

It is widely accepted between the scholars that emergencies are various and very diverse, they include external violent attacks, internal disturbances such as revolutions, natural disasters (environmental catastrophes are also included), epidemics and economic crisis

\footnotetext{
* PhD, Senior Lecturer, University of Pécs, Faculty of Law. Email: meszaros.gabor@ajk.pte.hu.
} 
(Sajó \& Uitz, 2017, 419). According to Subrata Roy Chowdhury (Chowdhury, 1989, p. 1516), there are three different situations which may arouse the need of state of emergency. The first could be grave political crises with violence, such as are armed conflicts, terrorist attacks, rebellions and riots. The second category involves natural disasters and industrial accidents, while the third is an economical and financial crisis. These categories may require different actions from the states, for example, a violent crisis may require a prompt and definite reaction from the government (or from the legislation), while an economic crisis - mostly - allows for more extended response periods. Chowdhury's ordination has to be amended with a new one which category is already the reality of our life and can be described as the concept of a permanent state of emergency. The background of this issue is that the global climate change and the technological development results in new challenges which have already become the core elements of our everyday living and also raise the question: is it possible to maintain the classical view of the rule of law and constitutionalism?

\section{THE QUESTION OF CONSTITUTIONALISM IN THE CONTEXT OF STATE OF EXCEPTION}

There are at least two main problems with the responses to an emergency. First of all, the state must respond to an emergency effectively and therefore shall use measures which are not allowed during normal times. It is the state's responsibility to protect itself and also the nation, but the more serious question is how a state deal with an emergency and at the same time could protect the values of constitutionalism?

The core element of constitutionalism means a wide range of principles, theories, values and institutions that are concerned with the authorization, organization, direction and most importantly, the constraint of political power. 'Constraint' means that neither anarchy nor a totalizing concentration of power is consistent with constitutionalism. A constitutionalist system includes three immanent elements, and if only one is lacking, the system is not constitutional. First: the institutions authorized by and accountable to the people. Second: some notion of limited government (there are already various types of this element). Third: the rule of law. There are other essential elements as well such as sovereignty, a written constitution, some form of judicial review, and the presence of a civil society autonomous from the government (Brandon, 2015, p. 763). The aim of constitutionalism with its various principles is limiting government power in order to prevent despotism. Therefore, constitutionalism suggests that authority may be limited by various techniques of separation of powers, checks and balances, and the protection of human rights. Thus, constitutionalism presumes a legally binding document (the constitution) which provides the necessary limitations of government (sovereign) power (Sajó \& Uitz, 2017, 13). However, constitutionalism has a more or less strict system of requirements; the elements of the rule of law can be more diverging. The reason behind this is that the rule of law is a jurisprudential topic; therefore, we have to take into account the historical, cultural and sociological aspects. The common element of the rule of law is the significant limitation of possible arbitrary power (Selznick, 1999, p. 21). It is also more 
or less evident that in the post-socialist or "transition" countries (such as Hungary) the Courts (especially the Constitutional Courts) made great efforts in order to support and to consolidate constitutionalism and the rule of law (Örkény \& Scheppele, 1999, p. 58-65).

These principles are not only the essential elements of constitutionality, and therefore, constitutional democracy but also these values are the most vulnerable ones during a time of emergency. At this point, the effective judicial review is the only real guardian of constitutionalism and fundamental rights (Davis \& Londras, 2016).

\section{THE PROBLEM WITH EMERGENCIES}

As we had seen during the period of the Weimar Republic, the most dangerous aftermath of emergency regimes is the possibility for an authoritarian government to abuse emergency powers in order to stay in power. The Weimar Constitution was already accepted in a background of ominous use of emergency powers and delegated legislation with an economic crisis in a country without democratic backgrounds and commitment. It was also accepted to delegate legislation in a time of crisis if a law passed with a two-thirds majority and therefore legislative powers could be transformed to the executive. Furthermore, the president could pass decrees - with the prime minister's countersign - with a force of a statute in an undefined state of emergency according to Article 48 of Germany's Weimar Constitution (Mommsen, 1996, p. 56-57). This power was undefined and unrestrained, and in 1930's it was used to replace constitutional democracy and the Parliament's sole legislative power with a presidential government which was using decrees instead of statues (Sajó \& Uitz, 2017, p. 231, 420). So, a constitutional democracy needs to have strict limits for the duration, circumstances and scope of emergency powers. This phenomenon is the leading legal question of emergencies and can be described as the 'inside-outside' debate, which also reflects on the Janus-faced character of the state of emergencies. The starting point of this debate is reflected in the relationship with the rule of law and the exception. According to the German theorist Carl Schmitt, "the sovereign is he who decides on the state of exception" (Schmitt, 2005, p. 5). This definition reflects on the decision and even more on the exception/normality dichotomy. The concept of the exception is based on the German political and economic crisis of the 1920-30s. Therefore, Schmitt tried to resolve these perils to the state by requiring the suspension of customary law. This approach which we call decisionist - prefers a sovereign decision against the norm.

Giorgio Agamben (Agamben, 1998, p. 17-18) calls this exception a "kind of exclusion". Moreover, "what is excluded in the exception maintains itself in relation to the rule in the form of the rule's suspension." In his work, Agamben tried to specify the nature of the state of emergency, which he called 'zone of indifference.' Agamben's definition contradicted the inside/outside opposition theories concerning the state of exception and focused instead on the characteristics of the norm, the judicial order and the suspension. In his view, the state of emergency (or state of exception, as he calls it, Agamben, 2005, p. 23) is "neither external nor internal to the juridical order [...] The suspension of the norm does not mean its abolition, and the zone of anomie that it establishes is not (or at least claims not to be) unrelated to the juridical order." 
On this decisionist ground Gross also emphasized that the officials must step outside the legal order if a particular case necessitates it (Gross \& Aioláin, 2006). Gross's concept also contains the assumption that the rule continues to apply in general. Finally, it is up to the people to ex-post ratify the official's extra-legal actions or punish for the illegal conduct. This ex-post prosecution adds some kind of legality to this 'extra-legal measures model.'

Others emphasize the relevance of the rule of law even in a time of emergency. According to the former (Dicey, 1982, p. 182-183.), the state of emergency (martial law) "means the suspension of ordinary law and the temporary government of a country or parts of it by military tribunals is unknown". He asserted that the 'Declaration of the State of Siege' is unknown, and from this point of view he offers 'permanent supremacy of law' in times of emergency as well. On this theoretical background David Dyzenhaus (Dyzenhaus, 2006) questions the decisionist approach. This perspective tries to define who decides on what in a state of emergency, or more precisely, who decides on fundamental issues of legality. In his interpretation, the responses to emergencies should also be governed by the rule of law, and in this relation, the rule of law is nothing more than the rule of fundamental constitutional principles which protect individuals from the state's arbitrary action. He accepted, of course, that in a time of emergency, democracies have to suspend individual rights in order to preserve themselves. However, he also added that in our modern era there are several emergencies (such as terrorism, and here I also add financial and economic crisis) which have no foreseeable end, and therefore they are permanent. For those who are troubled with the trend that a state of emergency could last for an uncertain period, Dyzenhaus offered the rule of law project. The phenomenon contains the cooperation of the legislative and the executive power and a significant role of the judges. He also mentioned that the rule of law meant more than formal or procedural principles, which could be regulated in the constitution, and which only protect the rights to the manner of decision-making. This concept of the rule of law with the state of emergency reflects the moral resource of law or the inner morality of law (Dworkin, 2013, 400-415). Taking everything into consideration, he asserted that judges have an essential task in maintaining the rule of law.

The theories resulted in at least two models of the state of emergencies: the 'legislative' and 'executive model' of emergency powers. The former requires the legislative body to design a sui generis 'emergency' legal regime in order to handle the situation. The latter is the most commonly used constitutional method which delegates the executive (especially the president or the government) the authority to decide the existence of an emergency and if it is the case to respond to it by using emergency or extra-legal measures. In a rule of law perspective, it is also vital to grant the possibility of judicial review, and if judicial supervision is given a relatively large role, one might see a third constitutional state of emergency model: the 'judicial model' (Dyzenhaus, 2012, 442).

To summarize the theories as mentioned earlier, there are two endpoints of emergency theories. On the one hand, when a state deals with an emergency, it might use extra-legal measures, so it is evident that the rule of law does not have a full impact on emergency politics. This theory is called the 'exceptionalist view' (Lazar, 2009, p. 3) which says that norms are applied in everyday situations, but during exceptional times these rules are not in effect, therefore, the emergency powers do not violate the rule of law and human 
rights because one can hardly violate a rule that is not in effect. The concept and theory of exception in a constitutional point of view nearly means a temporary dictatorship, although it is not as simple as we think. There is a big difference between a state of emergency and dictatorship: according to the previous, it is evident that although the standard rules do not apply there are other rules that do which means that there are some legal aspects during a state of emergency. Because of this nature of the state of exception, Clinton Rossiter used the framework of Constitutional Dictatorship in order to characterize the ambivalent nature of the state of emergency (Rossiter, 2009).

There is also the option with the nearly full power of legality; in this case, the rule of law has its effect on emergency politics, practically due to the effective judicial review. The problem with this standpoint is that with a full judicial review power on the one side, the other side, namely effective state self-defence and security could suffer great sacrifices. Consider, for example, that broad judicial review can also entail belated emergency measures, and in this way, the state cannot fight effectively against the emergency.

Another vital aspect might represent the core problem of the first standpoint. If we accept that there is a constitutional authority to use the law itself to suspend the law, and in this way, we create an exceptional regime near or upon the ordinary legal order, then we claim that the responses to an emergency mean a dualist legal order - one which response to everyday situation, and the 'emergency law' which response to exceptional situations.

Nearly all constitutional democracies use state of emergency regimes implemented into the constitutions which - in a theoretical point of view - means the in practice constitutional democracies accept the so-called exceptionalist viewpoint. By the way, one has to be aware to prevent the abuse of emergency powers in order to prevent the autocratic transition we had seen during the 'Weimar era'. Therefore, it is widely accepted that in modern constitutional democracies, emergency regimes are meant to be temporary with a precise aim to restore the usual way of constitutionalism. It also means that the emergency rules of constitutions have to fit some regulatory requirements in order to prevent the abuse of constitutionalism (Sajó \& Uitz, 2017, p. 424-433). It is widely accepted that national constitutions shall use exact constitutional definitions of emergencies which means some kind of taxation (with explanations as well) of the specific scenarios of external, violent attacks, internal disturbances and various national emergencies. It is also essential to rule the exact procedure for declaring an emergency, and it is also essential to include some kind of checks in the system in order to prevent the values of constitutionalism and the rule of law. The sui generis emergency regime can be easily separated from emergency measures which are indispensable to restore constitutional normalcy.

It is also widely accepted between constitutional law theorists that a state of emergency is generally meant to be temporary in the definition. The restrictions of the rule of law values and fundamental rights should not last longer than necessitated to handle the emergency, and these measures aim to restore the functioning of the standard constitutional system. Finally, there has to be a 'follow-up' procedure implemented to review and end the taken emergency measures (Sajó \& Uitz, 2017, p. 432-433). This element is crucial because, without it, there is a real threat that emergency measures are leaking into the standard legal order, which can lead to the erosion of constitutional values. 


\section{THE HUNGARIAN 'EMERGENCY REGIME’ AND COVID-19}

The Fundamental Law of Hungary created a sui generis state of emergency chapter, which means that it follows an 'exceptionalist view'. This chapter is called the special legal orders, which contains the state of national crisis and emergency, state of preventive defence, state of danger and unforeseen intrusion. Article 54 of the Basic Law also represents the standard rules relating to special legal order, such as the possibility to suspend or restrict fundamental rights beyond the extent of ordinary law standards. This article contains unique guarantees such as the prohibition of suspension of the Fundamental Law and other temporal restrictions. Although the Fundamental Law has a visibly unified emergency power system it also has to be indicated, that the prelude of Hungary's new constitution had a connection with the political and economic crisis as well and the constitution has its 'crisis-constitution' nature (Mészáros, 2018, p. 278-282). Not to mention that the Hungarian Parliament also used ordinary legislation, which contains extra-legal measures in order to deal with so-called emergencies as we have seen during the 'mass migration crisis' which resulted in a new emergency regime outside the Fundamental Law's mechanism (Mészáros, 2017, p. 135-137).

Soon after the official declaration of the first infection by the new coronavirus on 4 March 2020, the government declared a state of emergency (state of danger) using Article 53 of the Fundamental Law by Decree 40/2020 (III. 11.). The first paragraph of Article 53 allows the government to declare a state of danger and to introduce emergency measures - these measures defined in an implementing act (The Act CXXVIII of 2011 on emergency management and the amendment of specific relevant laws) - in the case of a natural or industrial disaster endangering lifes and property or to mitigate the consequences thereof. During a state of danger, the government may issue decrees empowered - under the implementing act of Act CXXVIII of 2011 on emergency management and the amendment of specific relevant laws - to suspend the application of certain laws or to derogate from the provisions of laws, and to take other extraordinary measures. Nevertheless, this decree of the government shall remain in force for fifteen days only, except if the government based on an authorization from Parliament - extends the effect of the decree. According to the last paragraph of Article 53 upon the termination of the state of danger, the decree of the government should cease to affect.

It seems clear that the Fundamental Law is granting the opportunity to declare this kind of state of emergency and the implementing act is responsible for regulating the relevant emergency measures to be used in a state of danger. According to the Fundamental Law, there are only two relevant situations that would result in a state of danger: natural and industrial disasters. The human epidemic is not involved in the listing of the constitution. However, the relevant implementing act, Act CXXVIII of 2011 concerning disaster management and the amendment of specific relevant laws extends the cases by the 'other dangers' specified in Article 44, which allows declaring a state of danger to protect the health and life of citizens when a human epidemic jeopardizes human life and property and causes mass infections. Consequently, the Act overwrote the Fundamental Law's specification of the relevant cases and enabled the declaration of a state of danger by using a provision of the Act instead of 
the Fundamental Law. For the Fundamental Law, this provision is unconstitutional (for a detailed analysis on this matter see: Mészáros, 2020). The government can declare the state of danger by a decree, and it is also possible for the government to use temporary nullification measures - it can be found in the Act on Emergency Management - but this latter Act cannot ease the enumeration of the Constitution.

After the declaration of a state of danger, the Hungarian government issued more than a hundred decrees and also used ordinary legislation to handle the situation. The most controversial was the so-called 'Enabling Act', which was accepted by 2/3rd of the Parliament on Monday 30 March and was signed by the President within two hours. This 'Enabling Act' has given the Government free rein to govern directly by decree without the constraint of existing law. It has also allowed suspending the enforcement of specific laws, departed from statutory regulations and implemented additional extraordinary measures by decree in addition to the extraordinary measures and regulations outlined in Act CXXVIII of 2011 concerning disaster management and the amendment of specific relevant laws. The government could have taken these measures by referring to the 'Enabling Act' instead of corresponding to the Fundamental Law's strict emergency regime, which means that the coronavirus situation led to an anomalous situation (Mészáros, 2019, 63-72). The Hungarian legislation and government used a hybrid regime - which means extra-legal measures implemented into the standard legal order - in order to handle the pandemic emergency.

\section{CONCLUSIONS}

As I have briefly mentioned above the coronavirus situation called worth the rethinking of state of exception's classical theories because it seems that the Hungarian Fundamental Law's regime was ineffective at least in two ways: first of all the government believed that with the available constitutional state of emergency rules the situation could have hardly been handled effectively. Secondly and most importantly, in this way, the constitutional guarantees were not sufficient enough to preserve the rule of law values and to help to regain normalcy. I agree that times of emergency put the rule of law to its most significant test (Dyzenhaus, 1999) when people rely on political leaders who are using sovereign prerogative but behind these acts one can easily find out that the aim is to act for the public good (Sarat, 2010, p. 1). It is also important to mention that the real relevance of law is to fulfil the requirements which rule of law values generate in constitutional democracies. Therefore, it is evident that the rule of law (as an essential requirement of law-making) is about tempering power and arbitrariness (Krygier, 2016). If the law has an alternate objective, it proposes constitutional concerns. Based on Hans Kelsen's theory, modern constitutional democracies are constructing emergency powers with the assumption of separating normalcy from the emergency. Therefore, they use emergency measures separated from ordinary rules (Gross, 2018, 585). These regulation aims to assure that extra-legal measures can be used solely in extraordinary times; therefore, the taken actions remain separated from normalcy. State of emergencies used worldwide in context with the threat of coronavirus has raised the critical question again, especially in Hungary: is it possible to make bright-line distinctions between normalcy and the state of emergency in an era 
when the emergency government is becoming the norm (Gross \& Aoláin, 2006, p. 171243)? The question asked by the famous legal theorist Ronald Dworkin is also remaining: How far do our moral obligations and responsibilities depend on what the law provides and do we have a moral obligation to obey the law, whatever it is (Dworkin, 2013, p. 401)? I am afraid we have to wait and see for the answer until the end of the situation caused by the coronavirus. 


\section{REFERENCES}

Agamben, G. 1998. Homo Sacer: Sovereign Power and Bare Life. Stanford: Stanford University Press.

Agamben, G. 2005. State of Exception (Kevin Attell trans.). Chicago-London: University of Chicago Press.

Brandon, M. E. 2015. Constitutionalism. In: Tushnet, M., Graber, M. A. and Levinson, S. (eds.), The Oxford Handbook of the U.S. Constitution, Oxford: Oxford University Press, pp. 763-784.

Chowdhury, S. R. 1989. The Rule of Law in a State of Emergency - The Paris Minimum Standards of Human Rights Norms in a State of Emergency. London: Printer Publisher.

Davis, F. F. \& de Londras, F. eds. 2016. Critical Debates on Counter-Terrorism Judicial Review. Cambridge: Cambridge University Press.

Dicey, A. V. 1982. Introduction to the Study of the Law of the Constitution. 8th ed. Indianapolis: Liberty Classics.

Dyzenhaus, D. 1999. Legality and Legitimacy: Carl Schmitt, Hans Kelsen and Hermann Heller in Weimar. New York: Oxford University Press.

Dyzenhaus, D. 2012. States of Emergency. In: Rosenfeld, M. and Sajó, A. (eds.), The Oxford Handbook of Comparative Constitutional Law. Oxford: Oxford University Press, pp. 442-462.

Dyzenhaus, D. 2006. The Constitution of Law: Legality in a Time of Emergency. Cambridge: Cambridge University Press.

Dworkin, R. 2013. Justice for Hedgehogs. Cambridge-Massachusetts-London: Harvard University Press.

Gross, O. 2018. The Normal Exception. In: Graber, M. A., Levinson, S. and Tushnet, M. (eds.), Constitutional Democracy in Crisis? Oxford: Oxford University Press.

Gross, O. \& Ní Aoláin, F. 2006. Law in Times of Crisis - Emergency Powers in Theory and Practice. Cambridge: Cambridge University Press.

Krygier, M. 2016. The Rule of Law: Past, Presents, and Two Possible Futures. Annual Review of Law and Social Science, 12, pp. 199-229.

Lazar, N. L. 2009. States of Emergency in Liberal Democracies. Cambridge: Cambridge University Press.

Mészáros, G. 2018. Constitutionalism in Crisis? - Emergency models in Constitutional Democracies. Budapest: Menedzser Praxis (Hungarian)

Mészáros, G. 2020. Carl Schmitt in Hungary: Constitutional Crisis in the Shadow of Covid-19. Review of Central and East European Law, Forthcoming in 2020 or 2021 (already accepted for publication) 
Mészáros, G. 2019. Is it Justified to Use Emergency Powers during Coronavirus Pandemic?: Constitutional Concerns regarding the 40/2020 Governmental Decree. Fundamentum, 23 (3-4), pp. 63-72. (Hungarian)

Mészáros, G. 2017. The Hungarian Response to Terrorism: a 'Blank Check' for the Government. Pécs: Studia Iuridica Auctoritate Universitas Pecs Publicata Yearbook 2016, 154, pp. 129-142.

Mommsen, H. 1996. The Rise and Fall of Weimar Democracy (Robert Forster and Larry Eugene Jones trans.). Chapel Hill: University of North Carolina Press.

Örkény, A. \& Scheppele, K. L. 1999. Rules of Law: The Complexity of Legality in Hungary. In: Krygier, M. and Czarnota, A. (eds.), The Rule of Law after Communism. London: Routledge. pp. 55-76.

Rossiter, C. 2009. Constitutional Dictatorship - Crisis Government in the Modern Democracies. 6th ed. New Brunswick: Transaction Publishers.

Sajó, A. \& Uitz, R. 2017. The Constitution of Freedom - An Introduction to Legal Constitutionalism. Oxford: Oxford University Press.

Sarat, A. (ed.) 2010. Sovereignty, Emergency, Legality. Cambridge: Cambridge University Press.

Schmitt, C. 2005. Political Theology: Four Chapters on the Concept of Sovereignty (George Schwab trans.). Cambridge: University of Chicago Press.

Selznick, P. 1999. Legal Cultures and the Rule of Law. In: Krygier, M. and Czarnota, A. (eds.), The Rule of Law after Communism. London: Routledge. pp. 21-39. 